Pacific Journal of Mathematics

REAL REPRESENTATIONS OF GROUPS WITH A SINGLE 


\section{REAL REPRESENTATIONS OF GROUPS WITH A SINGLE INVOLUTION}

\section{M. IsAACS}

\section{If $G$ is a finite group containing just one involution and $G$ has a faithful, absolutely irreducible real representation, then $G$ has order 2 .}

This was proved by Jerry Malzan [2] using the classification of simple groups with dihedral Sylow 2-subgroups. The purpose of this note is to give a proof of Malzan's theorem which assumes nothing but some elementary character theory.

Let $G$ have the unique involution $z$ and assume $G\rangle\langle z\rangle$. Let $\chi \in \operatorname{Irr}(G)$ be faithful and real valued (where $\operatorname{Irr}(G)$ is the set of complex irreducible characters of $G$ ). By the Frobenius-Schur theory (see Lemma 4.4 and Corollary 4.15 of [1]) it follows that in order to prove that $\chi$ is not afforded by a real representation, it suffices to show that

$$
\sum_{g \in G} \chi\left(g^{2}\right) \neq|G|
$$

THEOREM. In the above situation we have

$$
\sum_{g \in G} \chi\left(g^{2}\right)<|G| \text {. }
$$

Proof. Each $g \in G$ may be uniquely factored as $g=\sigma c$ where $\sigma$ has 2-power order and $c \in \boldsymbol{C}(\sigma)$ has odd order. We write $\sigma=g_{2}$. For each cyclic 2-subgroup $U \subseteq G$ we set $Y(U)=\left\{g \in G \mid\left\langle g_{2}\right\rangle=U\right\}$. Thus the sets $Y(U)$ partition $G$. We shall prove

$$
\begin{gathered}
\sum_{g \in Y(1)} \chi\left(g^{2}\right)=\sum_{g \in Y \backslash\langle z\rangle)} \chi\left(g^{2}\right)<|G| / 2 \\
\sum_{g \in Y(U)} \chi\left(g^{2}\right) \leqq 0 \text { if } \quad|U|=4 \\
\sum_{g \in Y(U)} \chi\left(g^{2}\right)=0 \text { if } \quad|U| \geqq 8 .
\end{gathered}
$$

The theorem will then follow.

Proof of (1). $\quad Y(1)$ is the set of elements of $G$ of odd order and since $z \in \mathbb{Z}(G)$, we have $Y(\langle z\rangle)=z Y(1)$ and so $\sum_{Y(1)} \chi\left(g^{2}\right)=\sum_{Y\langle\langle z\rangle} \chi\left(g^{2}\right)$. Since the map $g \mapsto g^{2}$ is a permutation of $Y(1)$, the common value of these sums is

$$
s=\sum_{g \in Y(1)} \chi(g) \text {. }
$$


If $\alpha$ is any automorphism of the field $\mathbb{Q}(\chi)$, then there exists an integer $m$ with $(m,|G|)=1$ such that $\chi(g)^{\alpha}=\chi\left(g^{m}\right)$ for all $g \in G$. Since the map $g \mapsto g^{m}$ is a permutation of $Y(1)$, it follows that $s^{\alpha}=s$ and thus $s$ is rational.

Now let $\chi=\chi_{1}, \chi_{2}, \cdots, \chi_{n}$ be the distinct Galois conjugates of $\chi$ and let $\theta=\sum \chi_{i}$. Then $\theta$ is rational valued and hence $\theta(g) \in \mathbb{Z}$ and $\theta(g) \leqq \theta(g)^{2}$ for all $g \in G$. Furthermore, $s=\sum_{Y(1)} \chi_{i}(g)$ for all $i$ since $s$ is rational, and thus

$$
n s=\sum_{g \in Y(1)} \theta(g) \leqq \sum_{g \in Y(1)} \theta(g)^{2} .
$$
and so

Since $\chi(z g)=-\chi(g)$ for all $g \in G$, we have $\sum_{Y(1)} \theta(g)^{2}=\sum_{Y\langle\langle z\rangle} \theta(g)^{2}$

$$
\begin{aligned}
2 n s & \leqq \sum_{g \in Y(1) \cup Y\langle z\rangle)} \theta(g)^{2} \\
& \leqq \sum_{g \in G} \theta(g)^{2}=|G|[\theta, \theta]=n|G| .
\end{aligned}
$$

Therefore, $s \leqq|G| / 2$. In fact, this inequality is strict since otherwise $\theta(1)=\theta(1)^{2}$ and hence $\chi(1)=1$. Since $\chi$ is real-valued and faithful and $|G|>2$, this is impossible and (1) follows.

Proof of (2). Let $|U|=4$ with $\langle\sigma\rangle=U$. Since $C(\sigma)$ has a unique involution and a central element of order 4 , it follows that $\boldsymbol{C}(\sigma)$ has a cyclic Sylow 2-subgroup and therefore has a normal 2complement $N$. Thus $Y(U)=\sigma N \cup \sigma^{-1} N$. Since $\sigma^{2}=\left(\sigma^{-1}\right)^{2}=z$ and $\chi(z g)=-\chi(g)$ for all $g \in G$, we have

$$
\begin{aligned}
\sum_{g \in Y(U)} \chi\left(g^{2}\right) & =-2 \sum_{g \in N} \chi\left(g^{2}\right) \\
& =-2 \sum_{g \in N} \chi(g)=-2|N|\left[\chi_{N}, 1_{N}\right] \leqq 0
\end{aligned}
$$

since $g \mapsto g^{2}$ is a permutation of $N$.

Proof of (3). Let $|U| \geqq 8$ and let $V$ be the subgroup of order 4 in $U$. If $g \in Y(U)$ and $\tau \in V$, then $\tau g \in Y(U)$ and hence $Y(U)$ is a union of cosets of $V$ of the form $V x$ with $x \in C(V)$. Now

$$
\sum_{g \in V x} \chi\left(g^{2}\right)=2 \chi\left(x^{2}\right)+2 \chi\left(z x^{2}\right)=0 \text {. }
$$

\section{REFERENCES}

1. I. M. Isaacs, Character Theory of Finite Groups, Academic Press, New York, 1976.

2. J. Malzan, On groups with a single involution, Pacific J. Math., 57 (1975), 481-489. 3. — Corrections to On groups with a single involution, Pacific J. Math., 67 (1976), 555.

Received November 22, 1976. Research supported by Grant MCS 74-06398A02. 


\section{PACIFIC JOURNAL OF MATHEMATICS}

\section{EDITORS}

RICHARD ARENS (Managing Editor)

University of California

Los Angeles, CA 90024

Charles W. Curtis

University of Oregon

Eugene, OR 97403

C. C. MOORE

University of California

Berkeley, CA 94720

\section{J. DugundJI}

Department of Mathematics

University of Southern California

Los Angeles, CA 90007

R. FinN and J. Milgram

Stanford University

Stanford, CA 94305

ASSOCIATE EDITORS
E. F. BECKENBACH
B. H. NeumanN
F. WOLF
K. YOSHIDA

\section{SUPPORTING INSTITUTIONS}

UNIVERSITY OF BRITISH COLUMBIA CALIFORNIA INSTITUTE OF TECHNOLOGY

UNIVERSITY OF CALIFORNIA

MONTANA STATE UNIVERSITY

UNIVERSITY OF NEVADA, RENO

NEW MEXICO STATE UNIVERSITY

OREGON STATE UNIVERSITY

UNIVERSITY OF OREGON

OSAKA UNIVERSITY

\author{
UNIVERSITY OF SOUTHERN CALIFORNIA \\ STANFORD UNIVERSITY \\ UNIVERSITY OF HAWAII \\ UNIVERSITY OF TOKYO \\ UNIVERSITY OF UTAH \\ WASHINGTON STATE UNIVERSITY \\ UNIVERSITY OF WASHINGTON \\ AMERICAN MATHEMATICAL SOCIETY
}

The Supporting Institutions listed above contribute to the cost of publication of this Journal, but they are not owners or publishers and have no responsibility for its content or policies.

Mathematical papers intended for publication in the Pacific Jaurnal of Mathematics should be in typed form or offset-reproduced, (not dittoed), double spaced with large margins. Please do not use built up fractions in the text of your manuscript. You may however, use them in the displayed equations. Underline Greek letters in red, German in green, and script in blue. The first paragraph or two must be capable of being used separately as a synopsis of the entire paper. Items of the bibliography should not be cited there unless absolutely necessary, in which case they must be identified by author and Journal, rather than by item number. Manuscripts, in triplicate, may be sent to any one of the editors. Please classify according to the scheme of Math. Reviews, Index to Vol. 39. All other communications should be addressed to the managing editor, or Elaine Barth, University of California, Los Angeles, California, 90024.

The Pacific Journal of Mathematics expects the author's institution to pay page charges, and reserves the right to delay publication for nonpayment of charges in case of financial emergency.

100 reprints are provided free for each article, only if page charges have been substantially paid. Additional copies may be obtained at cost in multiples of 50 .

The Pacific Journal of Mathematics is issued monthly as of January 1966. Regular subscription rate: $\$ 7200$ a year (6 Vols., 12 issues). Special rate: $\$ 36.00$ a year to individual members of supporting institutions.

Subscriptions, orders for back numbers, and changes of address should be sent to Pacific Journal of Mathematics, 103 Highland Boulevard, Berkeley, California, 94708.

PUBLISHED BY PACIFIC JOURNAL OF MATHEMATICS, A NON-PROFIT CORPORATION

Printed at Kokusai Bunken Insatsusha (International Academic Printing Co., Ltd.). 8-8, 3-chome, Takadanobaba, Shinjuku-ku, Tokyo 160, Japan.

Copyright (C) 1975 by Pacific Journal of Mathematics Manufactured and first issued in Japan 


\section{Pacific Journal of Mathematics}

\section{Vol. 71, No. $2 \quad$ December, 1977}

Krishnaswami Alladi and Paul Erdős, On an additive arithmetic

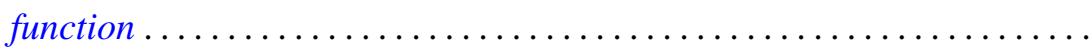

James Bailey and Dale Rolfsen, An unexpected surgery construction of a

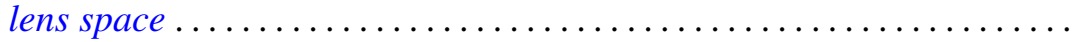

Lawrence James Brenton, On the Riemann-Roch equation for singular

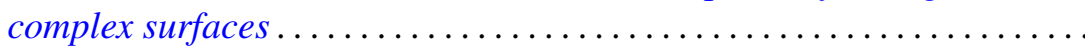

James Glenn Brookshear, Projective ideals in rings of continuous

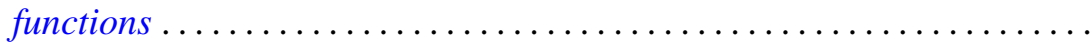

Lawrence Gerald Brown, Stable isomorphism of hereditary subalgebras of

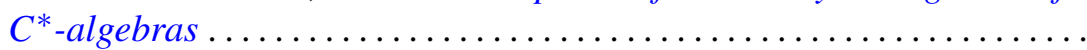

Lawrence Gerald Brown, Philip Palmer Green and Marc Aristide Rieffel, Stable isomorphism and strong Morita equivalence of $C^{*}$-algebras....

N. Burgoyne, Robert L. Griess, Jr. and Richard Lyons, Maximal subgroups

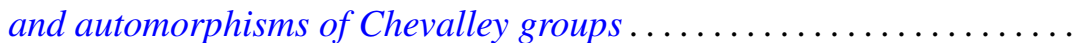
365

Yuen-Kwok Chan, Constructive foundations of potential theory .... 405

Peter Fletcher and William Lindgren, On $w \Delta$-spaces, $w \sigma$-spaces and

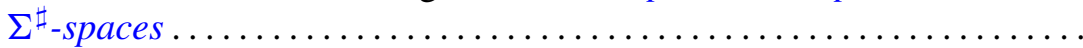

Louis M. Friedler and Dix Hayes Pettey, Inverse limits and mappings of

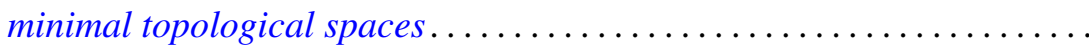

Robert E. Hartwig and Jiang Luh, A note on the group structure of unit regular ring elements.

I. Martin (Irving) Isaacs, Real representations of groups with a single involution ...

Nicolas P. Jewell, The existence of discontinuous module derivations . .

Antonio M. Lopez, The maximal right quotient semigroup of a strong semilattice of semigroups .......................

Dennis McGavran, $T^{n}$-actions on simply connected $(n+2)$-manifolds

Charles Anthony Micchelli and Allan Pinkus, Total positivity and the exact $n$-width of certain sets in $L^{1}$.

Barada K. Ray and Billy E. Rhoades, Fixed point-theorems for mappings with a contractive iterate .......................

Fred Richman and Elbert A. Walker, Ext in pre-Abelian categories. .

Raymond Craig Roan, Weak* generators of $H^{\infty}$ and $l^{1}$..

Saburou Saitoh, The exact Bergman kernel and the kernels of Szegö type...

Kung-Wei Yang, Operators invertible modulo the weakly compact 